\title{
CELLULAR IMMUNITY IN HUMAN HERPES VIRUSES 6 AND 7 INFECTED GASTROINTESTINAL CANCER PATIENTS
}

\author{
Inta Jaunalksne*,**, Simona Doniṇa ${ }^{*, * *}$, Svetlana Čapenko*, Maksims Čistjakovs*, \\ and Modra Murovska* \\ * August Kirchenstein Institute of Microbiology and Virology, Rīga Stradiṇš University, Rātsupītes iela 1, Rīga, LV-1067, LATVIA; \\ e-mail: i.jaunalksne@stradini.Iv \\ ** VSIA Pauls Stradiṇš Clinical University Hospital, Pilsoṇu iela 13, Rīga, LV-1002, LATVIA \\ ${ }^{* * \star}$ Rĩga Eastern Clinical University Hospital, Latvian Oncology Centre, Hipokrāta iela 4, Rīga, LV-1006, LATVIA
}

Contributed by Modra Murovska

\begin{abstract}
CD4+ T lymphocytes appear to be the preferential target for replication of HHV-6 (human herpes virus) as well as HHV-7 viruses in vivo. In addition, CD8+ T cells, monocytes/macrophages, natural killer cells, epithelial, endothelial, neural cells and fibroblasts may be infected. By definition, however, even a tumour designated by pathologists to be early stage may be late stage when considered by the immune system. Certainly, even early stage tumours have evaded immune control, suggesting that they have acquired many immunosuppressive characteristics. The aim of the study was to clarify the influence of beta-herpes viruses on cellular immune response. In 95 gastrointestinal cancer patients we determined the immunocompetent cell level CD3, CD4, CD8, CD19, CD38, CD95, CD25 using laser flow cytofluorimeter and B- herpes viruses HHV-6, HHV-7 presence using a nested polymerase chain reaction method. Our data showed no statistically significant difference in immunocompetent cell level between negative, latent and active HHV-6, HHV-7 infection. Patients with immunocompromised immune status (lymphopenia) had a tendency to decreased $C D 4^{+}, C D 19^{+}$absolute count. It may be suggested that virus-mediated immune response inhibition seems to be similar to cancer mediated, but differences in immune response among the same group of individuals had no influence on the average number of the immunocompetent cells in the group. Therefore, to characterise host-virus-tumour interactions, individual interpretation of each case is needed.
\end{abstract}

Key words: $H H V-6, H H V-7$, gastrointestinal cancer, cellular immunity.

\section{INTRODUCTION}

Cellular immunity is the most important part of the immune system in anticancer immune response. Numerous innate and adaptive immune effector cells and molecules participate in the recognition and destruction of cancer cells, a process that is known as cancer immunosurveilance. However, cancer cells avoid such immunosurveilance through the outgrowth of poorly immunogenic tumour cell variants, called immunoselection, and through suppression of the immune system (Zitvogel et al., 2006). Cancer-associated immunosuppression is mediated by evaluation of an immunosuppressive network that extends from the primary tumour site to secondary lymphoid organs and peripheral blood immunocompetent cells. Chronic stimulation of $\mathrm{T}$ cells by tumours leads to activation-induced cell death and insufficiency of cellular immune response.

It could be expected that each additional immunosuppressive factor contributes to the tumour escaping from immunological control and promotes cancer growth.
Human herpes viruses (HHV) are frequently present in patients with a compromised immune system and are described as immunotropic viruses that can infect several cells implicated in the generation of both cell-mediated and humoral immune response. Beta-herpes viruses HHV-6 and HHV-7 have some similar biological properties and both viruses are often recognised concomitantly, suggesting that viral syndromes may often be due to a combination of these viruses (Hall et al., 2006). HHV-6 and HHV-7 can induce immunosuppression by various mechanisms and triggering of apoptosis in lymphocytes is one of the most important (Mirrandola et al., 2006).

CD4+ T lymphocytes appear to be the preferential target for replication of HHV-6 as well as HHV-7 viruses in vivo. In addition, CD8+ $\mathrm{T}$ cells, monocytes/macrophages, natural killer (NK) cells, epithelial, endothelial, neural cells and fibroblasts may be infected (Clark, 2002; Dockrell, 2003; De Boele et al., 2005; Miyjake et al., 2006).

An effective CD4+ T cells response is believed to prevent tolerance induction by effective function of tumour antigen 
on cytotoxic CD8+ T cells, thereby preventing tumour escape from immunological control. Lack of CD4+ T cells help is also involved in the deletion of cytotoxic T Ly in the chronic viral infection. The persistent presence of low levels of antigens in these cases is similar to some cancers. Therefore, it is possible that cytotoxic $\mathrm{T}$ Ly against tumour antigens are deleted when $\mathrm{T}$ helper responses are absent (Kennedy and Celis 2006). Induction of $\mathrm{T}$ cells apoptosis by viruses is one of the mechanisms to destroy host immune system. Based on previous studies, it is known that resting $\mathrm{T}$ cells are not susceptible to Fas (CD95)-dependent apoptosis, but Fas-triggered $\mathrm{T}$ cells death happens in activated effector $\mathrm{T}$ cells upon encountering their antigens. Thus, active effector $\mathrm{T}$ cells will be eliminated and less active or suppressed T cells (CD95-) will be preserved (Lenardo, 1991; Russell et al., 1991).

Beta-herpes viruses frequently reactivated under immunosuppressive conditions, and reactivation of HHV-6 plays a significant pathologic role in immunocompromissed patients. The pathogenic significance of $\mathrm{HHV}-7$ reactivation remains uncertain, however, indirect effects of HHV-7 replication may include interactions between HHV-6 and -7, and the development of cytomegalovirus disease (Smith et al., 2001; Moussa et al., 2002).

By modulating specific antiviral immune response, betaherpes viruses can facilitate their own spread and persistence in vivo as well as contribute to the pathogenic effect of the other agents (Lusso, 2006). The risk of reactivation of HHV-6 and HHV-7 in different conditions of immunosuppressions has been clearly showed, and clinical attention should be paid to immunocompromissed patients with reactivated and persistently active HHV-6, HHV-7 infections at later ages (Cassula et al., 2001). HHV-6 and HHV-7 are frequently present in patients with various lymphoproliferative disorders including multiple mieloma, Hodgkin's disease, T-cell lymphoma and myeloproliferative syndromes. Additionally, HHV-6 has been linked to precancerous lesions of the uterine cervix (Tran-Thanh et al., 2002). Immunomodulating processes between host and virus during HHV-6 and HHV-7 infection in solid tumour patients were not widely investigated.

The interactions between beta-herpes viruses and the immune system have been extensively characterised using in vitro and ex vivo models while in vivo studies are still limited, as concluded by Lusso (2006).

Our aim was to clarify the influence of beta-herpes viruses on cellular immune response in gastrointestinal (GI) cancer patients before any antitumour treatment.

\section{MATERIALS AND METHODS}

We examined 95 gastrointestinal (GI) cancer patients before antitumour treatment. Patient age was from 38 to 75 years. Patients were divided into two groups according to lymphocyte count in peripheral blood: $\mathrm{Ly}>1400$ per $1 \mathrm{~mm}^{3}$ and
Ly $<14001 \mathrm{~mm}^{3}$ (group I and II, respectively). HHV-6 and HHV-7 were detected in both groups. Lymphocyte subpopulations were determined by a laser flow cytofluorimeter Becton Dickenson with corresponding monoclonal antibodies to $\mathrm{CD}^{+}, \mathrm{CD}^{+}, \mathrm{CD}^{+}, \mathrm{CD} 16^{+}, \mathrm{CD} 19^{+}, \mathrm{CD} 38^{+}$, $\mathrm{CD} 25^{+}, \mathrm{CD}^{+} 5^{+}$lymphocytes. Nested polymerase chain reaction (nPCR) was used for the identification of viral sequences in DNA isolated from peripheral blood leukocytes (PBL) and plasma (markers of latent/persistent and active infection, respectively). Total DNA was isolated from 0.5 $\mathrm{ml}$ of fresh whole blood by phenol-chloroform extraction, QIAamp DNA Blood Kit (Qiagen) was used for DNA purification from $200 \mu \mathrm{l}$ of cell free blood plasma. The plasma samples were treated with Deoxyribonuclease I before DNA purification. To assure the quality of the PBLs DNA as well as exclude contamination of plasma DNA by cellular DNA, a globin PCR was performed. PCR amplification for the viruses was carried out in the presence of $1 \mu \mathrm{g}$ of PBL DNA and $10 \mu \mathrm{l}$ of plasma DNA (corresponding to 100 $\mu \mathrm{l}$ of plasma). The detection of HHV-6, HHV-7 and CMV DNA was performed according to Secchiero et al. (1995) Berneman et al. (1992), and Studahl et al. (1995), respectively. Positive (virus genomic DNA) and negative (DNA without virus-specific sequences) and water controls were included in each experiment.

The investigation was carried out with approval of Ethics Committee of Rīga Stradiňs University and all patients gave their informed consent prior to the examination.

As statistical method, Fisher's exact test, NPar, Kruskal Walles test for statistical evolution of the results were used.

\section{RESULTS}

Patient distribution with HHV-6, HHV-7 is shown in Table 1. There was no statistically significant difference between leukocyte, lymphocyte, monocyte, neutrophile and CD3, CD4, CD8, CD38, CD16, CD19, CD95, CD25 cell absolute counts and $\mathrm{CD} 4 / \mathrm{CD} 8$ ratio between negative, latent and active HHV6 and HHV7 infection groups in GI cancer patients (Table 2). However, we observed a tendency that the number of CD3+, CD4+, CD8+, CD38+ and CD95+ cells increased in peripheral blood in GI cancer patients with active beta-herpes virus infection. It was surprising that the total count of CD16+ cells was not influenced by virus infection in our patients. Average count of the determined parameters in patients with Ly $>1,400$ (group I) and pa-

Table 1

HHV-6 AND HHV-7 IN GASTROINTESTINAL CANCER PATIENTS

\begin{tabular}{l|c|c|c}
\hline \multirow{2}{*}{ Infection stage } & HHV-6 & HHV-7 & HHV-6/HHV-7 \\
\cline { 2 - 4 } & n of patients (\%) & n of patients (\%) & n of patients (\%) \\
\hline Negative & $83(87.4)$ & $33(34.7)$ & $32(33.7)$ \\
Latent & $11(11.6)$ & $39(41.1)$ & $39(41.1)$ \\
Active & $1(1.1)$ & $23(24.2)$ & $24(25.3)$ \\
\end{tabular}

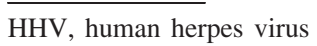


ABSOLUTE COUNT (MEAN \pm SD) OF LYMPHOCYTE SUBPOPULATIONS DEPENDING ON HHV6 AND HHV7 INFECTION IN GASTROINTESTINAL CANCER PATIENTS

\begin{tabular}{|c|c|c|c|c|c|c|c|c|c|c|}
\hline $\begin{array}{c}\text { HHV6+ } \\
\text { HHV7 } \\
\text { infection }\end{array}$ & $\begin{array}{c}\text { Ly } \times \\
10^{3} \\
\text { in } \mathrm{mm}^{3} \\
\end{array}$ & Mo & CD3 & CD4 & CD8 & CD1 & CD1 & $\mathrm{CD}$ & $\mathrm{CD}$ & $\mathrm{CD}$ \\
\hline & 66 & 0.54 & 1150 & 660 & 90 & 140 & 340 & 480 & 800 & 130 \\
\hline S & 0.76 & 0.2 & 610 & 380 & 330 & 120 & 250 & 250 & 430 & 80 \\
\hline & & & 1350 & 730 & & 14 & & & 95 & 170 \\
\hline $\mathrm{D}$ & 0.53 & 0.17 & 380 & 250 & 200 & 80 & 260 & 270 & 280 & 170 \\
\hline & 196 & 0.56 & 1450 & 780 & 540 & 20 & 34 & 530 & 1030 & 140 \\
\hline & & 0.25 & 730 & 360 & 550 & 170 & 230 & 220 & 560 & 70 \\
\hline
\end{tabular}

HHV, human herpes virus; Ly, lymphocyte; Mo, monocyte

Table 3

COUNT (MEAN \pm SD) OF IMMUNOCOMPETENT CELLS IN GI CANCER PATIENTS GROUP I $($ Ly $>1,400)$

\begin{tabular}{l|c|c|c|c|c|c|c|c|c|c}
\hline $\begin{array}{c}\text { HHV6+ } \\
\text { HHV7 } \\
\text { infection }\end{array}$ & $\begin{array}{c}\text { Ly } \times \\
10^{3} \\
\text { m }^{3}\end{array}$ & Mo & CD3 & CD4 & CD8 & CD19 & CD16 & CD38 & CD95 & CD25 \\
Negative & $\geq 1.4$ & 574 & 1489 & 857 & 616 & 164 & 430 & 618 & 1065 & 150 \\
& \pm SD & 168 & 660 & 407 & 408 & 83 & 287 & 252 & 436 & 93 \\
Latent & $\geq 1.4$ & 576 & 1461 & 795 & 634 & 156 & 388 & 592 & 1013 & 188 \\
& \pm SD & 170 & 335 & 234 & 188 & 80 & 272 & 272 & 259 & 186 \\
Active & $\geq 1.4$ & 622 & 1789 & 976 & 789 & 241 & 421 & 638 & 1267 & 152 \\
& $\pm S D$ & 278 & 635 & 259 & 619 & 188 & 240 & 193 & 535 & 82
\end{tabular}

HHV, human herpes virus; GI, gastrointestinal; Ly, lymphocyte; Mo, monocyte

Table 4

COUNT $($ MEAN \pm SD) OF IMMUNOCOMPETENT CELLS IN GI CANCER PATIENTS GROUP II (Ly $<1,400$

\begin{tabular}{l|c|c|c|c|c|cccc|c|c}
\hline $\begin{array}{c}\text { HHV6+ } \\
\text { HHV7 } \\
\text { infection }\end{array}$ & $\begin{array}{c}\text { Ly } \times \\
10^{3} \\
\text { in }^{3}\end{array}$ & Mo & CD3 & CD4 & CD8 & CD19 & CD16 & CD38 & CD95 & CD25 \\
\hline \multirow{2}{*}{ Negative } & $<1.4$ & 493 & 781 & 446 & 358 & 120 & 238 & 337 & 521 & 101 \\
& \pm SD & 244 & 200 & 199 & 142 & 52 & 40 & 136 & 169 & 58 \\
Latent & $<1.4$ & 413 & 890 & 479 & 404 & 118 & 159 & 285 & 644 & 76 \\
& \pm SD & 102 & 166 & 76 & 147 & 52 & 31 & 54 & 145 & 29 \\
Active & $<1.4$ & 460 & 758 & 400 & 356 & 107 & 197 & 312 & 543 & 103 \\
& $\pm S D$ & 142 & 264 & 164 & 189 & 71 & 35 & 58 & 165 & 38
\end{tabular}

HHV, human herpes virus; GI, gastrointestinal; Ly, lymphocyte; Mo, monocyte

tients with Ly $<1,400$ (group II) are shown in tables 3 and 4 , respectively.

Cellular immune parameters were determined in both immunocompetent ( $\mathrm{Ly}>1,400)$ and immunocompromised (Ly < 1,400) GI cancer patients groups, independently of beta-herpes virus infection. Number of T cells and NK cells was higher in patients without lymphopenia, as expected, while the total count of B cells and CD25+ cells was similar in both groups (Table 5).
ABSOLUTE COUNT (MEAN \pm SD) OF IMMUNOCOMPETENT CELLS IN GI CANCER PATIENTS IN GROUPS I AND II

\begin{tabular}{l|c|c|c}
\hline \multicolumn{1}{c|}{ Parameters } & $\begin{array}{c}\text { Group I } \\
\text { ly }>1400\end{array}$ & $\begin{array}{c}\text { Group II } \\
\text { ly }<1400\end{array}$ & $P$ \\
\hline L & $7140 \pm 2044$ & $5360 \pm 1962$ & $<0.001 *$ \\
Mo & $587 \pm 199$ & $460 \pm 190$ & $<0.05 *$ \\
CD3 & $1545 \pm 523$ & $802 \pm 209$ & $<0.001^{*}$ \\
CD4 & $854 \pm 299$ & $443 \pm 169$ & $<0.001 *$ \\
CD8 & $665 \pm 386$ & $369 \pm 151$ & $<0.001 *$ \\
CD38 & & & $<0.001 *$ \\
CD 16 & $609 \pm 248$ & $318 \pm 105$ & $<0.001 *$ \\
CD19 & $407 \pm 266$ & $209 \pm 129$ & 0.31 \\
CD95 & $175 \pm 19$ & $117 \pm 115$ & $<0.091^{*}$ \\
& & &
\end{tabular}

GI, gastrointestinal; $* P<0.05$; Ly, lymphocyte; Mo, monocyte

Comparative analysis of Ly subsets between groups I and II was performed. Each group was subdivided into non infected, latent and active HHV-6 and HHV-7 infected patient subgroups. Patients with a normal Ly count (group I) and active viral infection tended to have increased counts of CD3+, CD4+, CD8+, CD19+ and CD95+ cells (Table 3). The number of CD4+ T as well as CD19+ B cells in the patients with a lower Ly count (group II) and active HHV-6, HHV-7 infection tended to be lower (Table 4).

GI cancer patients with latent HHV-6, HHV-7 infection had the highest number of CD25+ T cells and the lowest number of CD4+ $\mathrm{T}$ cells among patients in group I; however, a significant difference in absolute counts of immunocompetent cells was not observed (Table 4). In contrast with group I, immunocompromised patients (group II) had the highest number of CD4+ T cells and the lowest number of CD25+ $\mathrm{T}$ cells between subgroups. There was no significant difference between negative, latent and active HHV-6, HHV-7 infection subgroups in both immunocompetent and immunocompromised GI cancer patients groups.

Different immune response was observed among patients in the same subgroup. Average count of Ly subsets in each of the patients did not reflect individual immune response and intensity of cellular immune reactions.

\section{DISCUSSION}

Despite immune response HHV-6, HHV-7 viruses are never completely eradicated from the host. A key feature of both viruses life-style in the human host is their ability to infect 
and survive, in a latent/persistent form, in the cells of the immune system. Modulation of functional properties of host immune factors is an important mechanism of evading the immune response or creating an environment in which the virus can survive (Clark, 2000; Dockrell, 2003). Our results show that patients with latent and active infection in comparison to negative had tendency to have higher number of CD3+, CD4+, CD8+, CD95+ cells. It may be explained by additional activation of immune cells due to viral infection. In beta-herpes viruses-infected patients persistent immune activation driven by constant supply of HHV-6 and HHV-7 antigens in chronic or latent infection was observed (Wang et al., 2006). In comparison, our data showed that patients with latent infection had in average higher CD3, CD4, CD8, CD38, CD95, CD25 absolute count than patients with negative HHV-6 and HHV-7 infection.

Reduced Th1 immune response was observed in HHV-6 infected individuals (Morel et al., 1998). We did not observe Th1 immune answer depression in our active, latent infection group. By definition, however, even tumour designated by pathologists to be early stage may be late stage when considered by the immune system. Certainly, even early stage tumours have evaded immune control, suggesting that they have acquired many immunosuppressive characteristics (Lu and Fink, 2008). Depression of cellular immunity could be observed at various stages of cancer and the absolute count of lymphocytes in peripheral blood could be the first and simple indicator of the immune system insufficiency. Therefore, we also look for our patients groups with different lymphocyte absolute counts. We found out, that GI patients with Ly $\left(<1.4 \times 10^{3}\right)$ and latent and active infection had suppressed inductor phase of cellular immune response and tendency to weaken humoral immune reactions.

Many studies have described beta-herpes virus ability to suppress $\mathrm{T}$ cell proliferation, to induce apoptosis of CD4+ T Ly, to alter the expression of some immune activation markers and to perturb the cytokine network (Peng et al., 2000; Dockrell, 2003; De Bolle et al., 2005). It has been observed that CD4+ T cells from HHV-6-infected individuals exert suppressive activity on the proliferation of native $\mathrm{T}$ cells (Wang et al., 2006). The authors hypothesised that the suppressive capacity of these CD4+ T cells could be attributed to a high population of $\mathrm{CD} 4+25+\mathrm{T}$ regulatory cells, which could be actively suppressing the immune response. Our data show that patients with latent infection had elevated CD 25+ cell absolute count, in comparison with negative and active infected patients. It is difficult to speculate on the role of CD 25+ in our case, as these changes are not so remarkable.

Saff et al. (2004) suggested that Fas (CD95+) or Fas-ligand (CD95-L+) deficient tumour-specific Th1 cells survive better in tumour-bearing mice. Moreover, these tumourspecific Th1 cells were more effective than wild-type Th1 cells at eliminating tumours. This implies that Fas-mediated activation-induced cell death could be a limiting factor in effective T-cell-mediated immunosurveilance and immune response. Our HHV-infected patients had a tendency to in- crease Fas cell absolute count. We could suggest that such activation may lead to cell immunocompetent cell apoptosis and immune response functional inability. According to some reports, NK cells could be involved in host-virus interaction by different manner: NK could be infected by beta-herpes viruses and probably change their functional activity as well as T cells (Kruger, 1990; Clark, 2002; Migake et al., 2006), and beta-herpes viruses could increase NK cell activity via the cytokine network (Atedroe et al.,1997). Our patients did not show difference in CD16 absolute count. Lymphopenic patients with latent and active HHV-6, HHV-7 infection had decreased mean CD16+ absolute count in comparison with patients who were free from infection. We speculate that CD $16+$ cells were deleted (or they were infected).

There were some attempts to find relationships between beta-herpes virus infections and carcinogenesis based on observations that HHV-6 can directly infect CD4+ cells and induce apoptosis in immunocompetent cells, and that the virus can also infect thymic epithelial cells, hematopoietic stem cells and NK cells which are very important for immune maturation and protection against cancer and viral infections. Thus, HHV-6 infection may contribute to cancer circuitously through immune suppression (Kruger et at., 1990). Later studies were focussed on virus-induced immunosuppression or virus influence on the immune system of imnosuppressed patients. Gastrointestinal malignances are associated with a compromised immune system and viruses may be able to utilise cellular mechanisms responsible for immune response inhibition. Our findings show that patients who are compromised (lymphopenic) and had HHV-6, HHV-7 infection had greater immune response deviations than patients who are not immunocompromised. Virus-mediated immune response inhibition seems to be similar with cancer mediated. The study combining both virus- and cancer-mediated immune suppressive mechanisms will help us to understand complicated host-tumour interactions in vivo.

\section{ACKNOWLEDGEMENTS}

The work was supported by the National Research Programme in Medicine 2006-2009, project No. 11, "Immunomodulating viruses: strategy of infection diagnostics and opportunities to correct the treatment". Special thanks to professor Uldis Teibe advices on statistical analysis.

\section{REFERENCES}

Ablashi, D.V., Lusso, P., Hung, C.L., Salahuddin, S.Z., Josephs, S.F., Llana, T. et al. (1988). Utilization of human hematopoietic cell lines for the propagation and characterization of HBLV (human herpesvirus 6). Int. J. Cancer., 42, 787-791.

Berneman, Z.N., Ablashi, D.V., Li, Ge., Eger-Fletcher, M., Reitz, M.S., Chia-Ling, Hung et al. (1992). Human herpesvirus-7 is a T-lymphotropic virus and is related to, but significantly different from human herpesvirus-6 and human cytomegalovirus. Proc. Natl. Acad. Sci. USA, 89,10552-10556.

Burd, E.M., Carrigan, D.R. (1993). Human herpesvirus 6 (HHV-6)-associated dysfunction of blood monocytes. Virus Res., 29, 79-90. 
Casuta, M., Mock, D., Dentrust, S. (2001). Human herpesviruses 6. Clin. Infect. Dis., 33, 829-833.

Clark, D.A. (2000). Human herpesvirus 6. Rev. Med. Virol., 10, 155-173.

Clark, D.A. (2002). Human herpesvirus 6 and Human herpesvirus 7: Emerging pathogens in transplant patients. Int. J. Hematol., Suppl II, 246-252.

De Bolle, L., Naesens, L., De Clercq, E. (2005). Update on human herpesvirus 6 biology, clinical features and therapy. Clin. Microbiol. Rev., 18, 217-245.

Dockrell, D.H. (2003). Human herpesvirus 6: Molecular biology and clinical features. J. Med. Micobiol., 52, 5-18.

Flamand, L., Gosselin, J., Stefanescu, I., Ablashi, D., Menezes, J. (1995). Immunosuppressive effect of human herpesvirus 6 on T-cell functions: Suppression of IL-2 synthesis and cell proliferation. Blood, 85,1263-1271.

Kennedy, R., Celis, E. (2006). T helper lymphocytes rescue CTL from activation-induced cell death. J. Immunol., 177, 2862-2872.

Knox, K.K., Carrigan, D.R. (1994). Disseminated active HHV-6 infection in patients with AIDS. Lancet, 343, 577-578.

Kondo, K., Kondo, T., Okuno, T., Takahashi, M., Yamanishi, K. (1991). Latent human herpesvirus 6 infection of human monocytes/macrophages. $J$. Gen. Virol., 72, 140.

Lenardo, M.J. (1991). Interleukin-2 programs mouse alpha beta T lymphocytes for apoptosis. Nature, 353, 858-861.

Miyjake, F., Yoshikawa, T., Sun, H., Kakimi, A., Ohashi, M., Akimoto, S. et al. (2006). Latent infection on human herpesvirus 7 in CD4+ T lymphocytes. J. Med. Virol., 78, 112-116.

Mirandola, P., Spodzilli, I., Solenghi, E., Micheloni, C., Rinaldi, L., Gobbi, G. et al. (2006). Down-regulation of human leukocyte antigen class I and II and beta- 2 microglogulin expression in human herpesvirus- 7 infected cells. J. Infect. Dis., 133, 917-926.

Morel, P.A., Oriss, T.B. (1998). Crossregulation between Th1 and Th2 cells. Crit. Rev. Immunol., 18, 275-303.
Moussa, G., Ashi-Sulaiman, A., Levy, G. et al. (2002). Clinical impact of human herpesvirus 6 infection after liver transplantation. Transplantation, 73, 599-604.

Peng, G.Y., Yao, K., Ren, Q. (2000). Effects on production of TNF-alpha, IFN-gamma, IL-10 and IL-12 in lymphocytes by human herpesvirus 6 and 7 in vitro. Microbiol. Immunol., 20, 576-9.

Russell, H.J., White, C.L., Loh, D.Y., Melucly-Ray, P. (1991). Receptor-stimulated death pathways is opened by antigen in mature T cells. Proc. Natl. Acad. Sci. USA, 88, 2151-2155.

Saff, R.R., Spanjaard, F.S., Hohlbaum, A.M., Marshak-Rothstein, A. (2004). Activation-induced cell death limits effector function of CD4 tumor-specific T cells. J. Immunol., 172, 6598-6606.

Secchiero, P., Carrigan, D.R., Asano, Y., Benedetti, L., Crowley, R.W., Komaroff, A.L. et al. (1995). Detection of human herpesvirus 6 in plasma of children with primary infection and immunosuppressed patients by polymerasa chain reaction. J. Infect. Dis., 171, 273-80.

Smith, T.F., Wilson, J.A. (2001). Human beta-herpesvirus infections in solid organ transplant recipients. J. Infect. Dis., 183, 179-184.

Studahl, M., Bergstrom, T., Ekeland-Sjoberg, K., Ricksten, A. (1995). Detection of cytomegalovirus DNA in cerebrospinal fluid in immunocompetent patients as a sign of active infection. J. Med. Virol., 46, 274-280.

Tran Thanh, D., Koushik, A., Provencher, D. et al. (2002). Detection of human herpesvirus type 6 DNA in precancerous lesions of the uterine cervix. J. Med. Vir., 68(4), 606-610.

Yoshikawa, T., Ihira, M., Asano, Y. et al. (2002). Fatal adult case of severe lymphocytopenia associated with reactivation of human herpesvirus 6. $J$. Med. Virol., 66, 82-85.

Zitvogel, L., Tesnure, A., Kroemer, G. (2006). Cancer despite immunosurveilance: Immunoselection and immunosubversion. Nat. Rev. Immunol., 6, 715-727.

Received 11 July 2009

\section{ŠŪNU IMUNITĀTE AR HHV-6 UN HHV-7 INFICĒTIEM ZARNU TRAKTA VĒŽA PACIENTIEM}

Cilvēka herpes vīrusus konstatē cilvēkiem ar kompromitētu imūno atbildi. Herpes vīrusi spēj inficēt dažādas šūnas, ietekmējot gan šūnu, gan humorālo imunatbildi. HHV-6 un HHV-7 vīrusi spēj inficēt CD4 + T limfocītus, kā arī inficēt monocītus, makrofāgus, naturālos killerus, epitēlija, endotēlija, nervu šūnas un fibroblastus. Patologu noteiktā audzēja stadija ne vienmēr saskan ar imūnas sistēmas atbildes spēju, un jau agrīnās stadijās audzējs spēj pats radīt imūnsupresīvu vidi. Darba mērkiis bija noskaidrot $\beta$ herpes vīrusu ietekmi uz šūnu imūno atbildi. 95 kuṇga zarnu trakta vēža pacientiem noteicām CD3, CD4, CD8, CD19, CD38, CD95, CD25 absolūto šūnu līmeni, izmantojot lāzera plūsmas citoflorometrijas metodi. HHV-6, HHV-7 vīrusu klātbūtni noteicām ar nPCR metodi. Pacientiem ar negatīvu, latentu, aktīvu HHV-6, HHV-7 infekciju nekonstatējām statistiski ticamu diferenci noteikto imūnkompetento šūnu līmenī. Pacientiem ar kompromitētu imūno atbildi konstatējām zemāku CD4, CD19 absolūto skaitu. Audzēja mediētā imūnā atbilde ir līdzvērtīga imūnatbildei pacientiem ar HHV-6, HHV-7 aktīvu infekciju un limpopēniju. Viena tipa (latenta, aktīva pasīva) HHV-6, HHV-7 infekcijas pacientiem grupas robežās varam konstatēt atškirīgu imūnatbildi katram indivīdam, taču tas neietekmē grupas vidējos rādītājus. Tāpēc uzskatām, ka ir nepieciešams izvērtēt imūnatbildi katram pacientam individuāli. 